\title{
Synthesis and Pyrolysis of Thermosetting Copolymer of Polysilastyrene and Perhydropolysilazane
}

\author{
Osamu FUNAYAMA, Hiroki MOROZUMI, Mutsumi OKODA and Takeshi ISODA \\ Corporate Research and Development Laboratory, Tonen Corporation, 1-3-1, Nishi-Tsurugaoka, Ohi-machi, Iruma-gun, Saitama
}

\section{舟山 徹・両角宏喜・大小田睦美・礒田武志 \\ 東燃(株)総合研究所, 356 埼玉県入間郡大井町西鶴ケ岡 1-3-1}

熱硬化性ポリシラスチレンーペルヒドロポリシラザン共重合体の合成と熱分解

[Received October 20, 1994; Accepted February 21, 1995]

\begin{abstract}
Copolymer of polysilastyrene and perhydropolysilazane was obtained by the reaction of polysilastyrene with zirconium $n$-butoxide and perhydropolysilazane. Zirconium $n$-butoxide and perhydropolysilazane were essential to render the thermosetting property. The thermosetting copolymers were converted into silicon carbide-based ceramics by pyrolysis at $1000^{\circ} \mathrm{C}$ in a stream of $\mathrm{N}_{2}$ with about 80 mass $\%$ ceramic yield. The main phase of the pyrolysis product at $1500^{\circ} \mathrm{C}$ in $\mathrm{N}_{2}$ was small crystallite $\beta$-SiC. Free carbon, based on rule-ofmixtures composition in the final ceramics could be reduced by varying the ratio of polysilastyrene/ perhydropolysilazane. The copolymer was dry spun and pyrolyzed to produce a ceramic fiber. Pyrolysis in $\mathrm{N}_{2}$ at $1500^{\circ} \mathrm{C}$ yielded a silicon carbide-based fiber. Tensile strength of $1.0 \mathrm{GPa}$ and elastic modulus of $190 \mathrm{GPa}$ were obtained for the fiber from 10 to $12 \mu \mathrm{m}$ in diameter. Crystallization to $\alpha-\mathrm{Si}_{3} \mathrm{~N}_{4}, \beta-\mathrm{Si}_{3} \mathrm{~N}_{4}, \beta-\mathrm{SiC}$, and $\mathrm{ZrN}$ proceeded on annealing in $\mathrm{N}_{2}$ at $1700^{\circ} \mathrm{C}$ for $1 \mathrm{~h}$.
\end{abstract}

Key-words : Silicon carbide, Polymer, Pyrolysis, Zirconium, Silazane, Thermosetting

\section{Introduction}

Silicon carbide is a well-known ceramic material with high thermal and chemical stability, high mechanical strength and hardness, and high thermal conductivity. There has been much interest in the use of organosilicon polymers as precursors to silicon carbide-based ceramics. Some of the advantages in the preparation of ceramic materials from these precursors include compositional homogeneity in the final products, high purity ceramic products with uniform microstructure, amorphous to microcrystalline, and the preparation of refractory ceramics at relatively low temperatures.

- Yajima and his co-workers ${ }^{1)}$ developed polycarbosilane by thermal rearrangement of polydimethylsilane. Continuous $\mathrm{SiC}$ filament has been produced via pyrolysis of melt-spun polycarbosilane. ${ }^{2)}$ Babonneau and Soraru $\mathbf{u}^{3)}$ reported the structure and the pyrolysis process of polyzirconocarbosilane which was prepared from polycarbosilane and zirconium $n$ butoxide. West et al.4) prepared "polysilastyrene" by $\mathrm{Na}$ reduction of mixtures of $\mathrm{Me}_{2} \mathrm{SiCl}_{2}$ and $\mathrm{PhMeSiCl}_{2}$. Polysilastyrene is soluble in organic solvents and can be softened to viscous liquids at high temperatures. This polymer can be converted directly to silicon carbide, without prior conversion to a polycarbosilane. Ijadi-Maghsoodi et al. ${ }^{5)}$ demonstrated that silyene-acetylene could be synthesized by the reaction of dialkyl- or diaryldichlorosilanes with dilithioacetylene. These precursors were converted to silicon carbide-based ceramics by pyrolysis in inert atmosphere. However, curing process such as heat treatment in air, UV irradiation, and electron beam irradiation was essential for the preparation of shaped-SiC from thermoplastic precursors.

Several authors reported thermosetting $\mathrm{SiC}$ precursors. Schilling ${ }^{6)}$ described vinylic polysilane by refluxing various chlorinated silanes in a solvent with sodium. This vinylic polysilane was a viscous, liquid polymer that underwent thermal cross-linking in an inert atmosphere due to a combination of hydrosilylation and vinyl polymerization. Whitmarsh and Interrante. ${ }^{7)}$ reported hydridopolycarbosilane derived from (chloromethyl) trichlorosilane that underwent facile thermal cross-linking reactions. $\mathrm{Wu}$ and Interrante ${ }^{8)}$ prepared poly (silaethylene) by direct reduction of poly (dichlorosilaethylene) that was obtained via ring-opening polymerization of 1,1,3,3-tetrachloro-1,3-disilacyclobutane. The presence of $\mathrm{Si}-\mathrm{H}$ bonds in the polymers provided an effective thermosetting property. Toreki et al.9) produced silicon carbide fibers by pyrolysis of dry spun polycarbosilane without curing process. Molecular weight of polycarbosilane was controlled by separation of low molecular weight thermoplastic carbosilane.

We have described ${ }^{10)}$ the production of thermosetting $\mathrm{SiC}$ precusor by copolymerization of polycarbosilane with thermosetting perhydropolysilazane. This paper describes the synthesis of thermosetting preceramic polymer by copolymerization of polysilastyrene with perhydropolysilazane. Thermal cross-linking of perhydropolysilazane, below the softening point of polysilastyrene, was expected to render thermosetting property to the product 
copolymer. Properties of pyrolysis products as well as preliminary obtained ceramic fiber will be presented.

\section{Experimental procedure}

\subsection{Preceramic polymer synthesis}

Perhydropolysilazane (PHPS) was synthesized by ammonolysis of dichlorosilane-pyridine adduct followed by heat treatment at $120^{\circ} \mathrm{C}$ in pyridine with ammonia. ${ }^{11)}$

Commercially available polysilastyrene (PSS, Nippon Soda Co., Ltd., PSS-400) with number average molecular weight of 1300 was used in this study. The procedure is close to the one used by Yajima to prepare the Ti-modified polycarbosilane. ${ }^{12)}$ PSS and zirconium $n$-butoxide in given ratio $(\mathrm{Si} / \mathrm{Zr}=25 / 1$ (atomic ratio)) were dissolved in xylene to form a homogeneous solution. The solution was refluxed un$\operatorname{der} \mathrm{N}_{2}$ for $1 \mathrm{~h}$. After the refluxing reaction, the temperature was raised to $220^{\circ} \mathrm{C}$ and the xylene solvent was distilled off. The heat treatment was carried out at $220^{\circ} \mathrm{C}$ for $30 \mathrm{~min}$. After being cooled to room temperature, the product was dissolved in xylene. PHPS in xylene was added to the yellow solution in given ratios $(\mathrm{PSS} / \mathrm{PHPS}=2 / 1,1 / 1,1 / 4,1 / 6$ (Si ratio) ). The mixture was heated at $100^{\circ} \mathrm{C}$ under $\mathrm{N}_{2}$ for another $1 \mathrm{~h}$. The solvent was removed by vacuum distillation over a rotary evaporator to give light yellow powder.

\subsection{Pyrolysis}

Polymer samples were pyrolyzed in a carbon furnace (Model HG-010, Nikkato, Osaka, Japan) by heating from room temperature to $1500^{\circ} \mathrm{C}$ for 150 min, holding at $1500^{\circ} \mathrm{C}$ for an additional $60 \mathrm{~min}$, and cooled to room temperature in $150 \mathrm{~min}$. All heating was completed under a stream of $\mathrm{N}_{2}$.

\subsection{Characterization}

Infrared (IR) spectra were recorded on polymercoated KBr plates (Model 270-50, Hitachi, Tokyo, Japan). ${ }^{1} \mathrm{H}$ (Model R-24B, Hitachi, Tokyo, Japan) nuclear magnetic resonance (NMR) spectra were recorded for the polymers in $\mathrm{CDCl}_{3}$ solutions at room temperature. Elemental analyses for $\mathrm{Si}, \mathrm{N}, \mathrm{Zr}, \mathrm{C}, \mathrm{O}$ and $\mathrm{H}$ were obtained for the polymers and pyrolyzed samples. Differential scanning calorimetry (DSC) was carried out in $\mathrm{N}_{2}$ up to $500^{\circ} \mathrm{C}$ at a heating rate of $50^{\circ} \mathrm{C} / \mathrm{min}$ (Model DSC 7, Perkin-Elmer, Norwalk, U.S.A.). Thermogravimetric analysis (TGA) was performed on the polymer up to $1000^{\circ} \mathrm{C}$ under a stream of $\mathrm{N}_{2}$ (Model TG8110D, Rigaku, Tokyo, Japan) at a heating rate of $5^{\circ} \mathrm{C} / \mathrm{min}$.

$\mathrm{X}$-ray diffraction (XRD) measurements were performed on the pyrolyzed samples with $\mathrm{Cu} \mathrm{K} \alpha$ radiation using an automated powder diffractometer equipped with a monochromator (Model RINT 1400, Rigaku).

X-ray photoelectron spectroscopy (XPS) was carried out with $\mathrm{Mg} \mathrm{K} \alpha(1253.6 \mathrm{eV})$ radiation as the excitation source (Model $5600 \mathrm{CI}$, Perkin-Elmer). The analysis was performed, under a residual pressure at $6.66 \times 10^{-8} \mathrm{~Pa}$, on ground ceramic fibers. The XPS data recorded on the samples were calibrated utilizing the $\mathrm{Si} 2 \mathrm{p}$ binding energy in $\mathrm{SiC}(100.4 \mathrm{eV}$ as standard).

\subsection{Fiber preparation}

Polymer solutions were filtered to remove insoluble material and concentrated to develop appropriate rheological characteristics for the spining operation. Polymer fibers were continuously prepared by dry spinning at about $50^{\circ} \mathrm{C}$. With proper drawdown of the viscous polymer solution during extrusion from the spinneret, fibers with diameters of $12-15 \mu \mathrm{m}$ were produced. A drum on a variable speed motor was used for fiber takeup. Polymer fibers $(120 \mathrm{~mm}$ in length) were pyrolyzed in an $\mathrm{Al}_{2} \mathrm{O}_{3}$ tube furnace (Model F-1201, Nishimura Kogyo, Tokyo, Japan) under a stream of $\mathrm{N}_{2}$ at $5^{\circ} \mathrm{C} / \mathrm{min}$ to $1000^{\circ} \mathrm{C}$, holding at that temperature for $1 \mathrm{~h}$. The pyrolyzed fibers were subsequently annealed for $1 \mathrm{~h}$ under flowing $\mathrm{N}_{2}$ at $1500^{\circ} \mathrm{C}$ in a carbon furnace (Model HG-010, Nikkato, Osaka, Japan).

\section{Results and discussion}

\subsection{Characterization of copolymers}

The IR spectrum of PSS (as-received) is shown in Fig. 1 (A). The absorptions at $2900-3080 \mathrm{~cm}^{-1}$ (C$\mathrm{H}), 2100 \mathrm{~cm}^{-1}(\mathrm{Si}-\mathrm{H}), 1350-1450 \mathrm{~cm}^{-1}$ (C-H), $1250,1420 \mathrm{~cm}^{-1}\left(\mathrm{Si}-\mathrm{CH}_{3}\right), 1440,1100,740,700$ $\mathrm{cm}^{-1}(\mathrm{Si}-\mathrm{Ph}), 1040 \mathrm{~cm}^{-1}\left(\mathrm{Si}-\mathrm{CH}_{2}-\mathrm{Si}\right)$, and 800 $\mathrm{cm}^{-1}(\mathrm{Si}-\mathrm{C})$ are observed. The absorption at 2100 $\mathrm{cm}^{-1}(\mathrm{Si}-\mathrm{H})$ indicate that PSS was heat-treated and contains some carbosilane structures. The ratio of the intensity of the absorption of $\mathrm{Si}-\mathrm{H}$ bond at 2100 $\mathrm{cm}^{-1}$ to that of $\mathrm{Si}-\mathrm{CH}_{3}$ bond at $1250 \mathrm{~cm}^{-1}$ is 0.512 . The equivalent ratio for the reaction product of PSS with zirconium $n$-butoxide is 0.440 . This shows that some of the $\mathrm{Si}-\mathrm{H}$ bonds in PSS disappeared during

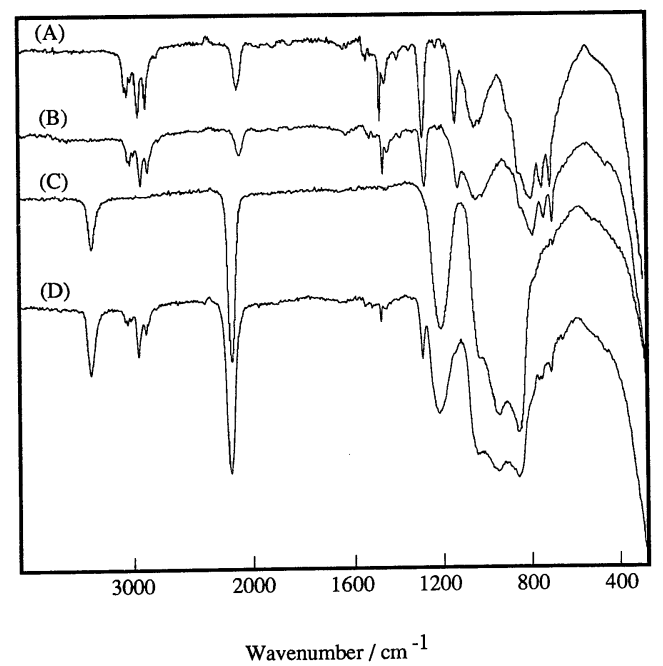

Fig. 1. IR spectra of (A) PSS, (B) PSS/zirconium $n$-butoxide ( $\mathrm{Si} / \mathrm{Zr}=25 / 1$ ), (C) PHPS, and (D) PSS/zirconium $n$-butoxide/ PHPS $(\mathrm{Si} / \mathrm{Zr}=25 / 1, \mathrm{PSS} / \mathrm{PHPS}=1 / 4)$. 
the reaction. The bonding between PSS and zirconium $n$-butoxide might be $\mathrm{Si}-\mathrm{O}-\mathrm{Zr}$. A small band at $480 \mathrm{~cm}^{-1}$ in Fig. 1(B) can be assigned to $\mathrm{Zr}-\mathrm{O} .^{3{ }^{1}}{ }^{1} \mathrm{H}$ NMR spectrum of PSS (as-received) reveals three peaks at $0.4 \mathrm{ppm}\left(\mathrm{SiCH}_{3}\right), 4.5 \mathrm{ppm}$ (weak; $\mathrm{SiH}$ ), and $7.3 \mathrm{ppm}(\mathrm{SiPh})$ (Fig. 2(A)). ${ }^{1} \mathrm{H}$ NMR spectrum of the reaction product of PSS with zirconium $n$ butoxide shows four new peaks at $0.95,1.4,1.6 \mathrm{ppm}$ $(\mathrm{CH})$, and $3.7 \mathrm{ppm}$ (weak; $\mathrm{OCH}_{2}$ ) (Fig. 2(B)). Zirconium $n$-butoxide can be incorporated as pendant substituents as the silicon sites of PSS. DSC curves of PSS (as-received) and the reaction product of PSS with zirconium $n$-butoxide show an endothermic peak starting at $210^{\circ} \mathrm{C}$, with a peak maximum at $230^{\circ} \mathrm{C}$ (Figs. 3(A) and (B)). These curves suggest

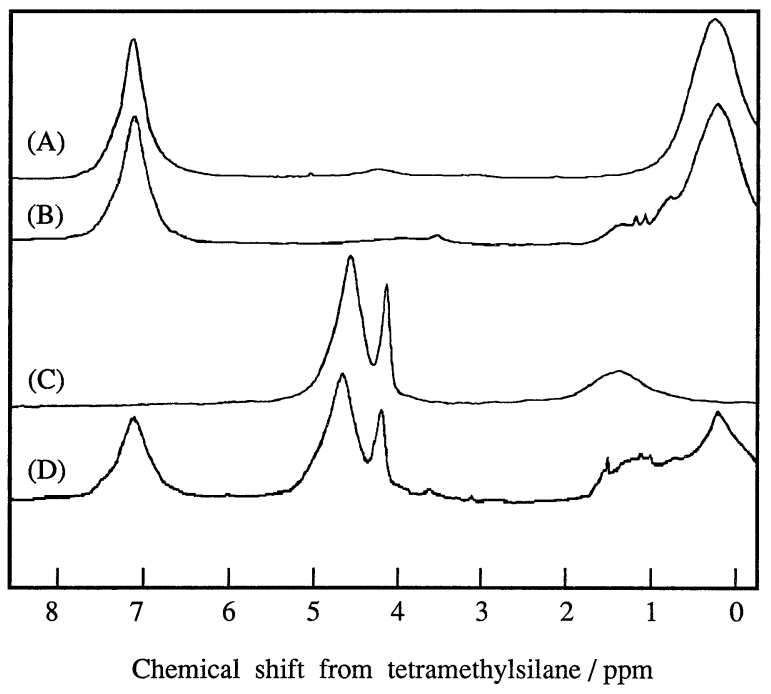

Fig. 2. ${ }^{1} \mathrm{H}$ NMR spectra of (A) PSS, (B) PSS/zirconium $n$ butoxide $(\mathrm{Si} / \mathrm{Zr}=25 / 1)$, (C) PHPS, and (D) PSS/zirconium $n$ butoxide/PHPS $(\mathrm{Si} / \mathrm{Zr}=25 / 1, \mathrm{PSS} / \mathrm{PHPS}=1 / 4)$.

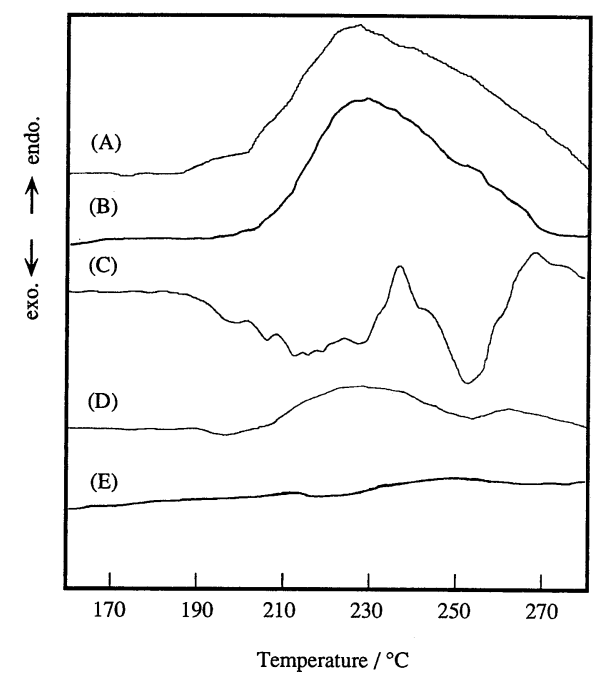

Fig. 3. DSC curves of (A) PSS, (B)PSS/zirconium $n$-butoxide $(\mathrm{Si} / \mathrm{Zr}=25 / 1$ ), (C) PHPS, (D) PSS/PHPS (PSS/PHPS $=1 / 4$ ), and $(\mathrm{E}) \mathrm{PSS} /$ zirconium $n$-butoxide/PHPS $(\mathrm{Si} / \mathrm{Zr}=25 / 1$, PSS/ PHPS $=1 / 4)$. that PSS and the reaction product of PSS with zirconium $n$-butoxide melt around this temperature.

The IR spectrum of PHPS (Fig. 1(C)) shows absorptions at $3400 \mathrm{~cm}^{-1}(\mathrm{~N}-\mathrm{H}), 2150 \mathrm{~cm}^{-1}(\mathrm{Si}-\mathrm{H})$, $1180 \mathrm{~cm}^{-1}(\mathrm{~N}-\mathrm{H})$, and $840-1020 \mathrm{~cm}^{-1}(\mathrm{Si}-\mathrm{N}-\mathrm{Si})$. The ratio of the intensity of the absorption of $\mathrm{N}-\mathrm{H}$ bond at $3400 \mathrm{~cm}^{-1}$ to that of $\mathrm{Si}-\mathrm{H}$ bond at 2150 $\mathrm{cm}^{-1}$ is 0.309 . The equivalent ratio for the reaction product of PSS/zirconium $n$-butoxide with PHPS $(\mathrm{Si} / \mathrm{Zr}=25 / 1, \quad \mathrm{PSS} / \mathrm{PHPS}=1 / 4) \quad$ (Fig. 1 (D) ) is 0.387 . This indicates that cleavage of some $\mathrm{Si}-\mathrm{H}$ bonds in PHPS occurred during the reaction of PHPS with PSS/zirconium $n$-butoxide. ${ }^{1} \mathrm{H}$ NMR spectrum of PHPS (Fig. 2(C)) reveals three peaks at $1.4 \mathrm{ppm}(\mathrm{NH}), 4.4 \mathrm{ppm}\left(\mathrm{SiH}_{3}\right)$, and $4.85 \mathrm{ppm}$ $\left(\mathrm{SiH} / \mathrm{SiH}_{2}\right)$. The ratio of the intensity of the signal of $\mathrm{SiH}_{3}$ at $4.4 \mathrm{ppm}$ to that of $\mathrm{SiH} / \mathrm{SiH}_{2}$ at $4.85 \mathrm{ppm}$ is 0.328 . The equivalent ratio for the reaction product of PSS/zirconium $n$-butoxide with PHPS is 0.296 . The decrease of the amount of $\mathrm{SiH}_{3}$ units in PHPS indicates that the reaction proceeded predominantly at these units in PHPS. The product copolymer might have some $\mathrm{Si}$ (PSS)-O-Zr-O-Si (PHPS) bondings. The DSC curve of PHPS (Fig. 3(C)) has exothermic peaks around $210^{\circ} \mathrm{C}$ and $250^{\circ} \mathrm{C}$ due to dehydrogenation of $\mathrm{Si}-\mathrm{H}$ and $\mathrm{N}-\mathrm{H}$ bonds. Thermal crosslinking around $210^{\circ} \mathrm{C}$ was expected to render thermosetting property to the copolymer. There is no endothermic peak around $230^{\circ} \mathrm{C}$ in the DSC curve of the product copolymer (Fig. 3(E)). This indicates that the product copolymer is thermosetting as expected.

Babonneau and Sorarú described ${ }^{3)}$ that no evidence for the presence of $\mathrm{Si}-\mathrm{O}-\mathrm{Zr}$ bonds could be found in the reaction product of polycarbosilane with zirconium $n$-butoxide. From the spectroscopic results of our polymers, there was no new signal observed for the presence of bondings between PSS and PHPS through zirconium $n$-butoxide. However, cleavage of the Si-H bonds in both PSS and PHPS occurred during the reaction. This might suggest the formation of $\mathrm{Si}-\mathrm{O}-\mathrm{Zr}$ bonds. Furthermore reaction product of PSS with PHPS (PSS/PHPS $=1 / 4$ ) without zirconium $n$-butoxide shows an endothemic peak around $230^{\circ} \mathrm{C}$ in the DSC curve (Fig. 3(D)). Zirconium $n$-butoxide was found to be essential for the polymer to show thermosetting property. This indicates that some bondings in the copolymer are necessary to show thermosetting property. Elemental analysis and DSC results for the polymers with varied PSS/PHPS ratio are summarized in Table 1. On

Table 1. Elemental Analysis and DSC Results of Copolymers with Different PSS/PHPS Ratios [(Total Si) $/ \mathrm{Zr}=100 / 1$ ]

\begin{tabular}{cccccccc}
\hline PSS/PHPS & \multicolumn{5}{c}{ Composition (mass\%) } & Endothermic peak at $230^{\circ} \mathrm{C}$ \\
\cline { 2 - 7 } (Si ratio) & $\mathrm{Si}$ & $\mathrm{N}$ & $\mathrm{Zr}$ & $\mathrm{O}$ & $\mathrm{C}$ & $\mathrm{H}$ & in DSC curve \\
\hline $2 / 1$ & 40.70 & 7.88 & 1.33 & 2.64 & 39.60 & 7.85 & yes \\
$1 / 1$ & 43.40 & 12.60 & 1.41 & 2.45 & 32.30 & 7.84 & no \\
$1 / 4$ & 49.20 & 22.90 & 1.60 & 2.23 & 16.80 & 7.27 & no \\
$1 / 6$ & 50.50 & 25.20 & 1.65 & 2.14 & 13.20 & 7.31 & no \\
\hline
\end{tabular}


the syntheses of these polymers, the ratio of PSS to zirconium $n$-butoxide was adjusted to give the same $\mathrm{Si} / \mathrm{Zr}$ ratio ((total $\mathrm{Si}) / \mathrm{Zr}=100 / 1$ ) in the products. The $\mathrm{Si} / \mathrm{Zr}$ ratio of the copolymers are found to be 99.7/1, 100.3/1, 100.2/1, and $99.7 / 1$ for PSS/ $\mathrm{PHPS}=2 / 1,1 / 1,1 / 4$, and $1 / 6$, respectively. The elemental analysis clearly shows the incorporation of the zirconium in the copolymers. The DSC result suggests that a certain amount of thermosetting units are necessary to render thermosetting property to the copolymer, even though the copolymer contained the bondings through zirconium $n$-butoxide. PHPS was essential (more than PSS/PHPS =1/1) to obtain copolymers with thermosetting property.

3.2 Conversion of the copolymers into silicon carbide-based ceramics

As shown in Fig. 4, the TGA curve of the copolymer (PSS $/ \mathrm{PHPS}=1 / 4$, (total $\mathrm{Si}) / \mathrm{Zr}=100$ / 1) indicates that the weight loss of the polymer starts around $100^{\circ} \mathrm{C}$ and is completed around $800^{\circ} \mathrm{C}$ in $\mathrm{N}_{2}$. Two regions are apparent in the TGA curve. The first region, below $300^{\circ} \mathrm{C}$, shows a weight loss of $2 \%$, which results from the decomposition of the zirconium $n$-butoxide. ${ }^{3)}$ The second region, from 300 to $800^{\circ} \mathrm{C}$, is thought to correspond to the breaking of organic bonds with the formation of gaseous species. The decomposition of PHPS is completed around $600^{\circ} \mathrm{C} .{ }^{11)}$ West et al. reported $^{4)}$ that PSS shows weight loss due to evaporation of $\mathrm{PhH}, \mathrm{H}_{2}$, and $\mathrm{CH}_{4}$, up to $800^{\circ} \mathrm{C}$. The second region in the TGA curve up to $600^{\circ} \mathrm{C}$ is due to the decomposition of both PHPS and PSS blocks, while from 600 to $800^{\circ} \mathrm{C}$ is certainly due to the decomposition of PSS block.

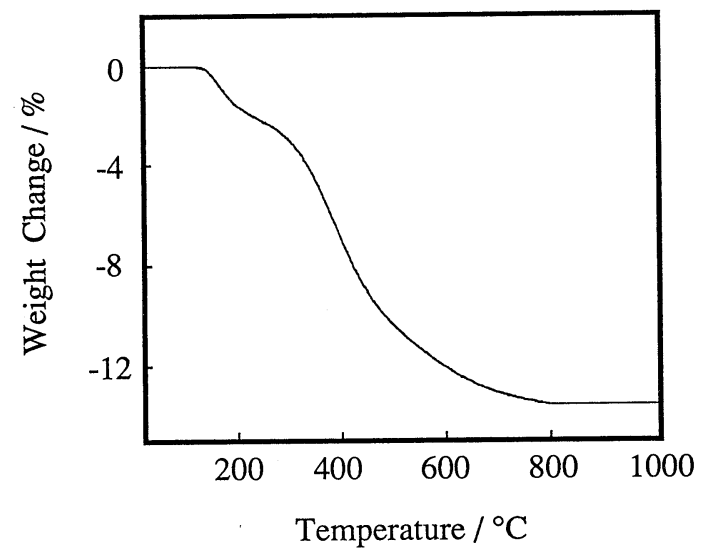

Fig. 4. TGA of the copolymer (PSS/PHPS $=1 / 4$, (Total Si)/ $\mathrm{Zr}=100 / 1)\left(\mathrm{N}_{2}\right.$ flow $: 100 \mathrm{~cm}^{3} / \mathrm{min}$, heating rate $\left.: 5^{\circ} \mathrm{C} / \mathrm{min}\right)$.

Table 2. Elemental Analysis and Rule-of-Mixtures Composition of Pyrolysis Products [Total Si) $/ \mathrm{Zr}=100 / 1]\left(\mathrm{N}_{2}, 1500^{\circ} \mathrm{C}\right)$

\begin{tabular}{|c|c|c|c|c|c|c|c|c|c|c|c|}
\hline \multirow{2}{*}{$\begin{array}{l}\text { PSS/PHPS } \\
\text { (Si ratio) }\end{array}$} & \multicolumn{6}{|c|}{ Composition (mass\%) } & \multicolumn{5}{|c|}{$\begin{array}{l}\text { Rule-of-mixtures composition } \\
\text { (moles relative to } \mathrm{SiC} \text { ) }\end{array}$} \\
\hline & $\mathrm{Si}$ & $\mathrm{N}$ & $\mathrm{Zr}$ & $\mathrm{O}$ & C & $\mathrm{H}$ & $\mathrm{ZrC}$ & $\mathrm{SiO} 2$ & Si3N4 & $\mathrm{SiC}$ & C \\
\hline $1 / 1$ & 53.50 & 14.00 & 1.73 & 2.94 & 27.20 & 0.70 & 0.018 & 0.086 & 0.21 & 1 & 1.1 \\
\hline $1 / 4$ & 58.30 & 18.20 & 1.98 & 2.64 & 18.20 & 0.70 & 0.021 & 0.08 & 0.32 & 1 & 0.46 \\
\hline $1 / 6$ & 61.00 & 20.20 & 2.02 & 2.60 & 13.60 & 0.60 & 0.022 & 0.079 & 0.35 & 1 & 0.09 \\
\hline PSS & 48.30 & 1.80 & - & 1.80 & 47.40 & 0.70 & - & 0.036 & 0.02 & 1 & 1.5 \\
\hline
\end{tabular}

The results of the elemental analysis of pyrolyzed samples are shown in Table 2. The nitrogen content in the ceramics are decreased in comparison with those in the polymers. Nitrogen has given off during the pyrolysis process, as expected from thermodynamic point of view. ${ }^{13)}$ Nitrogen in the pyrolyzed PSS was introduced during the pyrolysis in $\mathrm{N}_{2}$ atmosphere. Rule-of-mixtures compositions are calculated by assigning all $\mathrm{O}$ to $\mathrm{Si}$ as $\mathrm{SiO}_{2}$; all $\mathrm{N}$ to $\mathrm{Si}$ as $\mathrm{Si}_{3} \mathrm{~N}_{4}$; all $\mathrm{Zr}$ to $\mathrm{C}$ as $\mathrm{ZrC}$; then all $\mathrm{C}$ to $\mathrm{Si}$ as $\mathrm{SiC}$; excess $\mathrm{C}$ or $\mathrm{Si}$ is assumed to be in the elemental state. ${ }^{14)}$ Molar ratios, normalized to $\mathrm{SiC}$, are shown in Table 2. Ceramics derived from PSS/PHPS $=1 / 4$ contains small amount of elemental carbon, compared with that in pyrolyzed PSS. PHPS is excess in $\mathrm{Si}$, relating to $\mathrm{Si}_{3} \mathrm{~N}_{4}$. Elemental $\mathrm{Si}$ is formed by pyrolysis in $\mathrm{N}_{2}$ because nitrogen has given off. Elemental $\mathrm{Si}$ from PHPS compensates elemental C from PSS. Free $\mathrm{C}$ in the final ceramics can be reduced by varying ratio of PSS/PHPS.

XRD patterns of the pyrolyzed copolymers (PSS/ $\mathrm{PHPS}=1 / 1,1 / 4$, and $1 / 6$, (total $\mathrm{Si}) / \mathrm{Zr}=100 / 1$ ) are shown in Fig. 5. Ceramics derived from PSS/ $\mathrm{PHPS}=1 / 1$ shows a broad pattern characteristic of $\beta$-SiC of small crystallite size with a broad peak around $25^{\circ}$ which is assigned to $\mathrm{C}$ with poor crystallinity. Pyrolyzed PSS/PHPS $=1 / 4$ exhibits broad pattern charcteristic of $\beta$-SiC of small crystallite size with broad peak at $25^{\circ}$. The broad peak at $25^{\circ}$ is smaller than that of the pyrolyzed PSS $/ \mathrm{PHPS}=1 / 1$. It is consistent with the amount of excess carbon based on rule-of-mixture compositions. Ceramics from PSS $/ \mathrm{PHPS}=1 / 6$ shows patterns of $\alpha-\mathrm{Si}_{3} \mathrm{~N}_{4}$ on the halo of $\beta$-SiC and $\mathrm{C}$. Excess carbon, based on rule-of-mixture compositions, is present in ceramics from PSS $/ \mathrm{PHPS}=1 / 6$. However, crystallization of $\alpha-\mathrm{Si}_{3} \mathrm{~N}_{4}$ has proceeded. This indicates that some carbon precursors in the copolymer are stable and do not react with $\mathrm{Si}$. Above $800^{\circ} \mathrm{C}$, aromatics are the most stable hydrocarbons. The formation of aromatics from methyl radical, derived from methyl groups of PSS, can take place by way of formation of

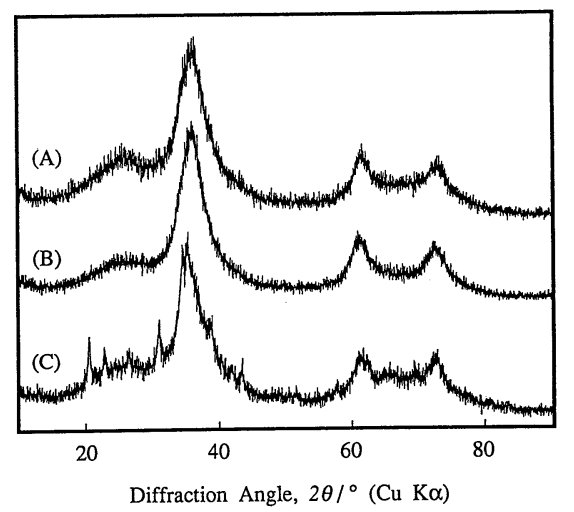

Fig. 5. X-ray diffraction patterns of pyrolyzed copolymers (A) $\mathrm{PSS} / \mathrm{PHPS}=1 / 1$, (B) PSS $/ \mathrm{PHPS}=1 / 4$, and (C) $\mathrm{PSS} / \mathrm{PHPS}=$ $1 / 6\left(\mathrm{~N}_{2}, 1500^{\circ} \mathrm{C}\right)$. 
hydrocarbons having a greater number of carbon atoms, formation of double bond, and Diels-Alder reactions. ${ }^{15)}$ During these multistage reactions, reactive species might react with $\mathrm{Si}$ and form $\mathrm{Si}-\mathrm{C}$ bond. On the other hand, phenyl radical, derived from phenyl groups of PSS, might form biphenyl. Heat treatment of biphenyl leads to planar mutiple ring structures, which is thought to be detected as $\mathrm{C}$ with poor crystallinity by XRD. Certain amount of free carbon should be formed if we try to suppress the crystallization of $\alpha-\mathrm{Si}_{3} \mathrm{~N}_{4}$ in the ceramics derived from PSS/PHPS at $1500^{\circ} \mathrm{C}$ in $\mathrm{N}_{2}$.

\subsection{Properties of ceramic fiber}

Copolymer of PSS/PHPS $=1 / 4 \quad($ total Si $) / \mathrm{Zr}=$ $100 / 1)$ is thermosetting and derived ceramics is amorphous. This copolymer was chosen to prepare a ceramic fiber.

Black shiny ceramic fiber with a diameter in the range of 10 to $12 \mu \mathrm{m}$ was obtained. The fiber contains 57.1 mass \% Si, 14.2 mass\% N, 18.8 mass\% C, 8.09 mass $\% \mathrm{O}$, and 1.86 mass \% Zr. Increase of oxygen content, in comparison with that of pyrolyzed powder, is due to oxygen inadvertedly introduced during the spinning and handling steps. Tensile strength and elastic modulus measured for this fiber

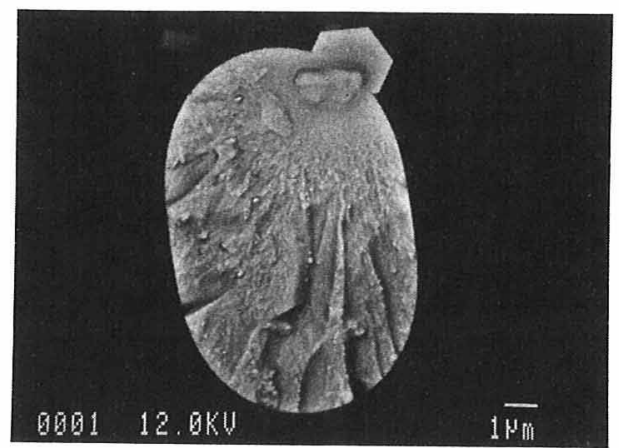

Fig. 6. Fracture surface of PSS/zirconium $n$-butoxide/PHPS derived fiber $\left(\mathrm{N}_{2}, 1500^{\circ} \mathrm{C}\right)$. were $\sigma=1.0 \mathrm{GPa}$ and $E=190 \mathrm{GPa}$. The fractograph (Fig. 6) showed a typical feature of tensile fracture of brittle materials. Crystallite was observed on the surface of the fiber. XRD pattern reveals the mixture of small crystallite $\beta$-SiC with poor crystallinity $\mathrm{C}$. Crystalline phase of the crystallite on the surface of the fiber could not be identified by XRD. However, low tensile strength of the fiber should be due to the crystallite which is thought to be a fracture origin. XPS analysis was performed on ground ceramic fiber. Figure 7 shows a plot of XPS binding energy for the fiber. A deconvolution analysis of the result shows that the Si $2 p$ peak is composed of three components; $\mathrm{Si}-\mathrm{O}(103 \mathrm{eV}), \mathrm{Si}-\mathrm{C}(101 \mathrm{eV})$, and an intermediate one $(102 \mathrm{eV})$. Si-N has a binding energy of $102 \mathrm{eV}$. The fiber contains 14.2 mass\% of nitrogen, and the signal at $102 \mathrm{eV}$ can be assigned to mixture of $\mathrm{Si}-\mathrm{N}$ with $\mathrm{O}-\mathrm{Si}-\mathrm{C}$ species. C 1s signal is composed of two components; $\mathrm{Si}-\mathrm{C}(283 \mathrm{eV})$ and $\mathrm{C}$ $(285 \mathrm{eV})$. This spectrum corroborates the existence of free carbon. $\mathrm{Zr}$ 3d signal is composed of four components; spin doublet $3 \mathrm{~d}_{1 / 2}-3 \mathrm{~d}_{3 / 2}$ assigned to $\mathrm{Zr}-\mathrm{O}$ $\left(180 \mathrm{eV}, 3 \mathrm{~d}_{3 / 2}\right)$ and $\mathrm{O}-\mathrm{Zr}-\mathrm{C}\left(182 \mathrm{eV}, 3 \mathrm{~d}_{3 / 2}\right)$. The fiber displays features of $\mathrm{Si}-\mathrm{C}$ with minor amount of $\mathrm{Si}-\mathrm{N}, \mathrm{O}-\mathrm{Si}-\mathrm{C}, \mathrm{Si}-\mathrm{O}, \mathrm{Zr}-\mathrm{O}, \mathrm{O}-\mathrm{Zr}-\mathrm{C}$, and free carbon.

For the elucidation of the crystallization behavior, the fiber was annealed in $\mathrm{N}_{2}$ at $1700^{\circ} \mathrm{C}$ for $1 \mathrm{~h}$. Weight loss of $13 \%$ was observed and the fiber turned green in color. XRD indicated the presence of crystalline $\alpha$ $\mathrm{Si}_{3} \mathrm{~N}_{4}, \beta-\mathrm{Si}_{3} \mathrm{~N}_{4}$, and $\beta$-SiC (Fig. 8). There was no peak assigned to $\mathrm{ZrO}_{2}$ or $\mathrm{ZrC}$. However, small peaks of $\mathrm{ZrN}$ were observed. $\mathrm{ZrN}$ can be formed by the reaction of $\mathrm{Zr}-\mathrm{O}$ with free carbon and atmospheric nitrogen. The annealed fiber possessed a porous, large-grained crystalline structure and was too weak to conduct tensile strength measurement.
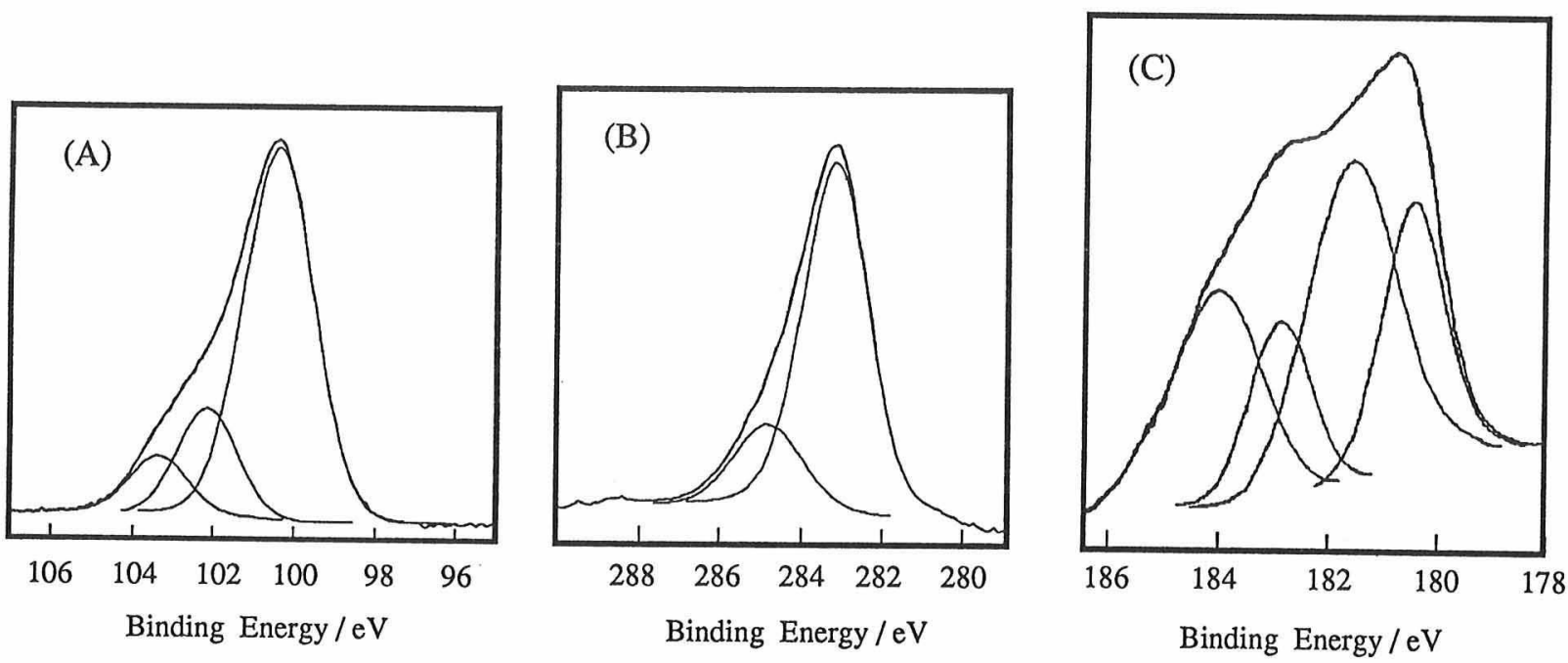

Fig. 7. XPS spectra of PSS/zirconium $n$-butoxide/PHPS derived fiber (A) Si 2p, (B)C 1s, and (C) Zr 3d. 


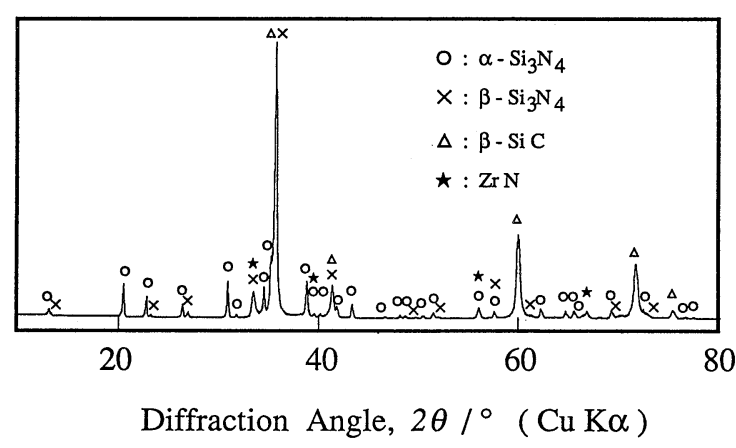

Fig. 8. X-ray diffraction pattern of ceramic fiber derived from PSS/zirconium $n$-butoxide/PHPS annealed in $\mathrm{N}_{2}$ at $1700^{\circ} \mathrm{C}$ for 1h.

\section{Conclusion}

Copolymer of PSS and PHPS was obtained by reacting PSS with zirconium $n$-butoxide and PHPS. Zirconium $n$-butoxide and PHPS (more than PSS/ PHPS $=1 / 1$ ) were essential for the polymer to show thermosetting property. The thermosetting copolymers were converted into silicon carbide-based ceramics by pyrolysis in a stream of $\mathrm{N}_{2}$ to $1000^{\circ} \mathrm{C}$ with about 80 mass\% ceramic yield. The main phase of the pyrolysis product at $1500^{\circ} \mathrm{C}$ in $\mathrm{N}_{2}$ was small crystallite $\beta$-SiC. Free carbon, based on rule-of-mixtures composition, in the final ceramics could be reduced by varying the ratio of PSS/PHPS.

The copolymer $(\mathrm{PSS} / \mathrm{PHPS}=1 / 4$, (total $\mathrm{Si}) / \mathrm{Zr}$ $=100 / 1$ ) was dry spun and pyrolyzed to produce ceramic fiber. Pyrolysis in $\mathrm{N}_{2}$ to $1500^{\circ} \mathrm{C}$ yielded a silicon carbide-based fiber. Tensile strength of $1.0 \mathrm{GPa}$ and elastic modulus of $190 \mathrm{GPa}$ were obtained for the fiber which ranged from 10 to $12 \mu \mathrm{m}$ in diameter. Crystallization to $\alpha-\mathrm{Si}_{3} \mathrm{~N}_{4}, \beta-\mathrm{Si}_{3} \mathrm{~N}_{4}, \beta$-SiC, and $\mathrm{ZrN}$ proceeded on annealing in $\mathrm{N}_{2}$ at $1700^{\circ} \mathrm{C}$ for $1 \mathrm{~h}$.

\section{References}

1) S. Yajima, J. Hayashi and M. Omori, Chem. Lett., 931-34 (1975).

2) S. Yajima, K. Okamura, J. Hayashi and M. Omori, J. Am. Ceram. Soc., 59, 324-27 (1976).

3) F. Babonneau and G. D. Sorarú, J. Eur. Ceram. Soc., 8, 2934 (1991).

4) R. West, L. D. David, P. I. Djurovich, H. Yu and R. Sinclair, Am. Ceram. Soc. Bull., 62, 899-903 (1983).

5) S. Ijadi-Maghsoodi, Y. Pang and T. J. Barton, J. Polm. Sci. Part $A$, 28, 955-65 (1990).

6) C. L. Shilling, Jr., Br. Polym. J., 18, 355-65 (1986).

7) C. K. Whitmarsh and L. V. Interrante, Organometallics, 10, 1336-44 (1991).

8) H. J. Wu and L. V. Interrante, Macromolecules, 25, 1840-41 (1992).

9) W. Toreki, G. J. Choi, C. D. Batich, M. D. Sacks and M. Saleem, Ceram. Eng. Sci. Proc., 13, 198-208 (1992).

10) O. Funayama, T. Aoki, T. Kato, M. Okoda and T. Isoda, submitted to J. Mater. Sci.

11) N. Kawamura and T. Isoda, JETI, 38, 104-08 (1990).

12) S. Yajima, T. Iwai, T. Yamamura, K. Okamura and Y. Hasegawa, J. Mater. Sci., 16, 1349-55 (1981).

13) H. D. Batha and E. D. Whitney, J. Am. Ceram. Soc., 56, 365-73 (1973).

14) J. Lipowitz, H. A. Freeman, R. T. Chen and E. R. Prack, Adv. Ceram. Mater., 2, 121-28 (1987).

15) E. Fitzer, K. Mueller and W. Schaefer, "Chemistry and Physics of Carbon", Ed. by P. L. Walker, Jr., Marcel Dekker (1971) pp. 237-383. 